\title{
The Psychology of Inclusion on New Media Platforms and the Online Communication
}

\author{
András ZELENA \\ Budapest Business School University of Applied Science \\ Budapest, Hungary \\ e-mail: zelena.andras@uni-bge.hu
}

\begin{abstract}
Following the tabooistic and rejective attitude of the $20^{\text {th }}$ century, in the processing and announcement method of the $21^{\text {st }}$ century, there is is a growing emphasis on sharing various life events on the platforms of new media (Web 2.0). Such platforms can be social media sites or one of the file or video sharing pages or blogs. In addition to presenting user habits shaped by the COVID pandemic, which have temporarily changed the online communication, I aim to answer the question of how new media (Web 2.0) becomes the platform of communal loss for users of different ages, genders, social statuses, and diverse Internet usage habits and socialization. I attempt to present the comprehensive picture of the transformation of personal loss into communal grief experience on the different platforms of new media and what supportive acts help the person who shares his/her loss experience in the processing of the events. By means of feedback (reactions, comments, replies with different emoticons), the user's loss experience "expands" into communal loss experience. In the present research paper, the findings of the international discipline are only applied to Hungary (its current population is 9.6 million), a Central Eastern European country where, according to a representative study published in 2015, there are 5 million Facebook users.
\end{abstract}

Keywords: loss announcement, grief, communal processing, new media, Web 2.0

\section{Introduction}

New media offers an ever-growing opportunity to announce and share various life events. Thus, loss experiences are also shared with acquaintances (and, as a consequence of the accessibility and operation principle of new media sites, with strangers as well) on these platforms. I have studied the complex manifestations and announcements of loss (hereinafter referred to as communication of loss and announcement of loss, or loss announcement) over the past year through selfadministered questionnaires and in-depth interviews. A detailed analysis of the 
results of my non-representative research has shown that the published events can be: the break-up of a relationship or divorce, sadness over the disappearance or passing away of a beloved pet, the trauma of relocation or changing jobs, documentation of illness on a blog, and in certain cases the process of dying recorded through the medium of online diary. One of the most widely quoted articles on the subject is the study entitled Who Interacts on the Web?: The Intersection of Users' Personality and Social Media Use by Correa, Hinsley, and Zúñiga (2010), published in Computers in Human Behaviour. I have used this study as a point of reference.

My hypothesis is that the personal loss experiences announced on the platforms of new media become communal loss experiences, and thus members of the community provide a kind of supportive care to the person who has suffered a loss. The interpretation of these processes offers possibility for further comparison in the context of Hungarian and international research results. In my research paper, the findings of the international discipline are only applied to Hungary (its current population is 9.6 million), a Central Eastern European country where, according to a representative study published in 2015, there are 5 million Facebook users. The research methodology combines the presentation of theoretical findings (similar to reviews but using the methodology of desk studies) and the conclusions of the in-depth interviews I conducted. I have deliberately chosen the age-groups represented by the graphs as both the OECD and the Active Ageing programme of the European Commission consider people aged 50 and over to be a single age-group. I followed the same practice.

Social media sites (Facebook, Twitter), blogs, the video sharing site youtube. com, and online memorial pages constitute the primary focus of my research. This study dedicates a chapter to each of these fields. I analyse the phenomenon of changing the profile picture to black, the changing of the relationship status without deleting the notification from the stream - which conveys a clear message -, while in another subchapter I discuss the blogs which document diseases and their treatment, all from the perspective of "loss communication".

Memorial videos - shared as public content on youtube.com - and their underlying messages, the way they are edited and their textual content are as much in the focus of my research interest as are the different manifestations of loss announcements appearing on online memorial pages and blogs. As the users of Web 2.0 offer a deeper and deeper insight into every moment of their lives, they transform their personal loss experiences into communal loss experiences. The articles and studies dealing with new media nicely demonstrate the interest of research on the high-priority role Web 2.0 has in communication research. Berners-Lee et al. (2006) published their article in Science, in which the community content, which allows content sharing and uploading opportunities, is referred to as Web 2.0. The study of Ajjan and Hartshorne (2008), which has been cited nearly one thousand times, examined empirically the educational 
applicability of Web 2.0, thus proving that Web 2.0 has become one of the basic components of the communication toolkit.

My aim is to answer the question of how new media (Web 2.0) becomes the platform of communal loss for users of different ages, genders, social statuses, and diverse Internet usage habits and socialization. For this purpose, I conducted a questionnaire-based survey. The analysis of communal processing of loss communication is also an integral part of my research. My study is strongly interdisciplinary: communication theory approaches are complemented by psychological research which deals with personal accounts of individual losses and traumas.

This review style paper must consider the COVID-19 pandemic and the way social and community media usage has been shaped by the global-scale social distancing (Howley, 2010) and must also look at the communication of losses related to this situation. The shift of communication channels produced by the sudden reduction of personal social relationships, telework, and curfews is an important communication theory topic. Amber Silver, a professor at Albany University, has published in this topic, focusing on how tourists and bloggers, vloggers, and professional journalists communicate (Silver, 2019). She points out that the unpredictability of the crisis has brought to the fore the influencertype opinion leaders, the creators of travel blogs and vlogs, and our network of personal acquaintances who were on their way when airports and hotels were closed down, because they provided first-hand, authentic information, unlike the news reports. Thus, in the midst of the pandemic, information sourced from social media content is considered authentic by users, and the pieces of information coming from personal acquaintances are valued above all. Fake news elements of social media communication are going to be mentioned later on in the paper.

\section{New Media}

In comparison with the linear communication channels, the platforms of new media offer the possibility of giving feedback and writing answers; thus, there is no clear boundary between personal and public communication and mass and interpersonal communication (McQuail, 2010). A new set of rules regarding the usage of new media is gaining ground among users, who should acquire new competencies as they must perform the cognitive process of reception and interpretation simultaneously. "Familiarity with the language of information technology and proficiency in the protocol and signs of the new communication culture become indispensable" (Aczél, 2015: 143).

New processes are appearing in the mechanism and quality of interpersonal relationships, and the boundary between the real self and the virtual face, the 
"public mask - false self" is radically blurred (Jenkins-Ford-Green, 2013). Several socio-psychological studies deal with the difference between the real self and the public mask, virtual face and the dangers implied by the phenomenon. The user takes on a certain role on the social media site. As if being one of the world's greatest restaurant critics, s/he publishes his/her selfies taken in restaurants and "mini-reviews" on end or, in another case, shares several pictures from the series What a wonderful parent I am while looking for the ideal picture location and setting even on the children's playground, hoping for the prospective likes. It is the serious distortion of the personality, of the real self-image when a person, unable to accept the passage of time and the aging process, shares years- or decades-old photographs accompanied by seemingly current textual content or spends hours touching up recent pictures in order to remove signs that give away their real age.

Consequently, the information in new media is not only the result of broadcasting but also that of collaborative creation; thus, new media, instead of dissemination, circulates the information (Jenkins-Ford-Green, 2013).

In addition to the classic contents, the so-called UGC (user-generated content) is also gaining ground. Users generate content with the help of professional technological tools, and thus everyone has the possibility to shape narratives. New media distinguishes itself from the earlier form of media through "key characteristics" such as digitalization, interactivity, hypertextuality, dissemination, and virtuality (Aczél, 2015: 147). What do interactivity and hypertextuality mean on the platforms of New Media? In this case, interactivity means that by complementing the classic ways of interactions there is the possibility of immediately sharing content with the network of acquaintances and the probability of receiving numerous answers within a few minutes. This process can be described with the notions: reciprocal influence of primary meanings and joint effect. The hypertextuality of the digital world emphasizes the coexistence of the original text and the metatext (comment, reply), and, because of the possibility to republish - to "copy" -, it separates the texts from their authors (Barthes, 1996; Szúts, 2011). In the $21^{\text {st }}$ century, even corporate dialogues unfold on new media platforms as these offer endless possibilities for the businesses to liaise with their customers (Anderson, 2006). Users create content together in the new media, as is the case, for example, in the Waze application, through which fellow drivers report hazards (object on road, construction), standstill, and traffic jam. On Wikipedia, we edit pages related to our hobbies, and on social media sites we recommend leisure time activities to our acquaintances. Instead of pictures taken by meteorologists or photographers, our photos submitted to the broadcasting company could appear on screen in the weather report.

The main corpus of my study is the field of social media sites, video sharing sites, and blogs, which, applying the term employed in the introduction, are the primary scenes for making announcements of loss. The studies which constitute 
the basic literature of this complex topic are compiled in the study of Ágnes Veszelszki and Andrea Parapatics (2014). These issues will be dealt with in more detail in the respective chapters.

\section{The Loss Communication of New Media}

A new special research synthesizes the findings of two $\mathrm{PhD}$ students (from the University of North Carolina at Charlotte and University of Kansas): "The sense of community processes can aid in the development of another community psychology value - sense of community, which is characterized by perceived similarity in identity, shared emotional experiences, and interdependence" (Maryman, 2016). In my opinion, the cited interdependence and shared emotional experience have a supportive and helping function in this case. The video In Memory of Joe Cocker 1944-2014, which was shared in 2015 on one of the most popular video sharing sites (youtube.com), was viewed by 5.3 million people until 11.09.2018. This shows that the site has become a platform for communal grief. In a previous study published in Kharon Thanatology Review (Zelena, 2016), I attempted to give an account of obituaries or funeral announcements published on the social media wall by users of different ages, genders, social statuses, and diverse Internet usage habits and socialization. I adapted the questionnaire, and in a self-administered questionnaire published on the most popular social media site in Hungary (in a non-representative study) I was looking for answers to the following questions:

1. How much time do you spend browsing social media sites?

2. Have you encountered announcement(s) of loss?

If yes, which were these? (several answers are possible)

3. Would you share your own loss experience on your wall?

When compiling the questionnaire, my aim was to get a clear picture of the loss communication appearing on the platforms of new media. My informants were men and women between the ages of 16 and 82, in proportional distribution (the eldest informant marked themselves as being 82 years old). As mentioned earlier, I have deliberately chosen the age-groups represented by the graphs as both the OECD and the Active Ageing programme of the European Commission consider people aged 50 and over to be a single age-group. I followed the same practice, representing every level of education from those who had completed 8 grades to those holding a $\mathrm{PhD} / \mathrm{DLA}$ degree. However, this research is non-representative, and my work is based on data gathered from self-administered questionnaires.

The answers to the question surveying the frequency of social media site usage are well dispersed: on one end, there are the users who log in once a month or once/twice a week, while on the other end there are those who spend more than 
3-4 hours online daily. The strongly similar answers of informants in the two agegroups - 16 to 29 and users 56 to 64 - create a set intersection.

How much time do you spend browsing social media sites?

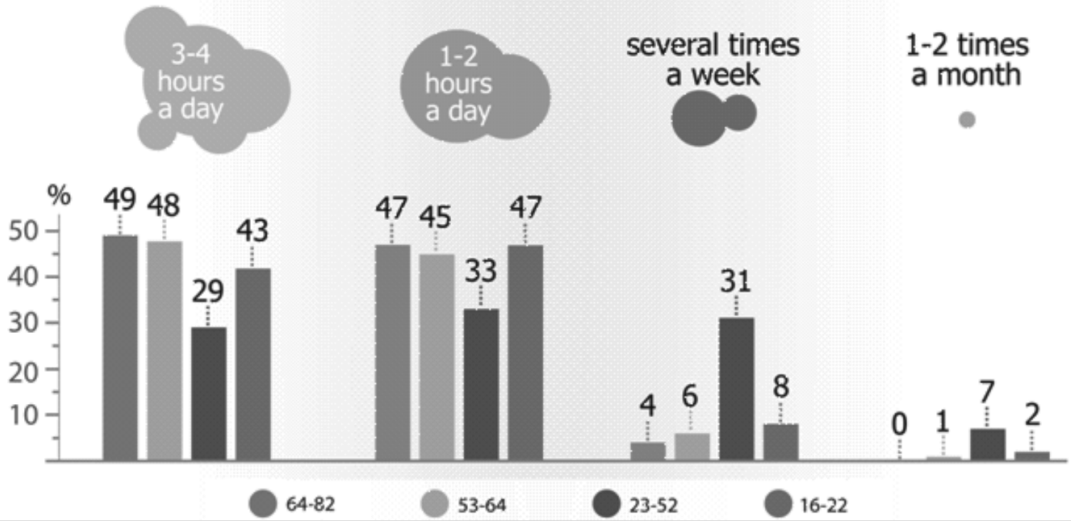

Figure 1. Frequency of social media site usage

The chart illustrates that a significant proportion of people aged 53 and above spend more than 3-4 hours a day on social media platforms. (An interesting finding of the survey is that users between the ages of 16 and 22 marked YouTube and messenger applications as the most frequently used ones.)

Have you encountered announcement(s) of loss?

If yes, which were these? (several answers are possible)

There was no such person in the group of informants who has never encountered some form of loss announcement. The analysis of the second part of the non-representative but large sample $(\mathrm{N}=387$ respondents) survey resulted in heterogeneous answers. A wide spectrum of loss announcements appears on the wall of social media sites as the loss experience involving the disappearance of a dog is published along with the trauma of retirement (the loss of permanence offered by the workplace and going to work, the loss of the feeling of being "an important and active person”). The pain caused by relocation, the separation from friends, acquaintances, and the old home was also mentioned. A significant proportion of the informants (almost 70\%) had encountered several times notifications regarding changes in the family status, which conveyed primary information, that is, many users had learnt about the divorce or break-up of their friends from these announcements. 93\% of the respondents mentioned the public posts commemorating the victims of a school bus tragedy (which had happened one month before the survey was carried out). Given the date of the 
survey, this is not surprising as the tragedy shaking the whole country was and still is actively present in the memory of the users in the period available for the filling in of the questionnaire. The rate of shares and publications on the social media site had been extremely high; thus, the number of wall posts had also grown radically. An interesting outcome of the survey is the fact that Facebook posts commemorating tragedies which happened a few years or even decades ago were also mentioned. In addition to the death of police psychologist Kata Bándy from Hungary, several respondents mentioned the wall posts commemorating the tragic death of Michael Jackson.

The research brought into my focus several other forms of loss communication in addition to death announcements: family status changes published on the wall of the social media site as well as indirect notices about break-ups and divorces. In a Facebook post encountered by one of my informants, a photo of a local court decision granting divorce was published accompanied by the following words: "Together till the end?! No comment."

Would you share your experience with loss on your Facebook wall?

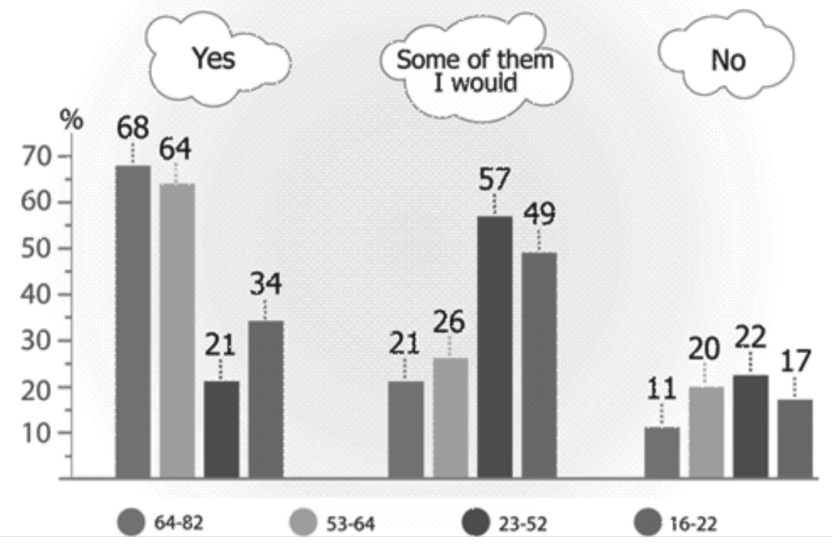

Figure 2. Would you share your experience with loss on your Facebook wall?

A distinct surveyed age-group can be identified when analysing my nonrepresentative research, as the members of the older generation are braver in publishing the announcement of their loss on the social media site. From indepth interviews, I found that several informants prefer notifications published in the virtual space to verbal manifestation because many people are incapable of the small talk and compulsory dialogue as they are retraumatized by the retelling of the suffered loss.

I see the explanation of the popularity of online sharing in the fact that members of the older generation rarely meet their acquaintances in person - in comparison with younger informants, who are in daily personal contact with their 
classmates, schoolmates, and friends. The relocations, which frequently involve moving from one city to another, make it impossible for elderly respondents to meet their friends and acquaintances in person. While the pandemic has led to the halt of economic growth resulting in serious public deficit, people must be also aware that fake news is expected to become excessively widespread, and users encounter them on community and social media platforms (Zing, 2020).

\section{Trauma and Video Sharing Websites}

In the aftermath of the war and the genocide, Dumisani Ngwenya (2017) summarizes the consequences of trauma and its mechanism of action in his study. The examination focuses on how social trauma takes place in the affected war zones. He defines the concept of "recovery" precisely and names the minimum condition for processing the traumas. He writes in the context of social science, politics, and psychology in one of his case studies, where he describes, for example, how people from Chile, Northern Ireland, and Ruanda handled the traumas, how quickly they recovered, and what strategies they used to process them. If the social traumas have such literature, it is appropriate to investigate deeper into how the personal traumas become communal on the Internet therefore, I will make an attempt to find this out. The study of $21^{\text {st }}$-century forms of absence and loss experience has been in the focus of my research interest for the past few years. Studying several aspects of the possibility of integrating memorial videos into the grieving process, I found that making and sharing memorial videos made up of photos edited into a slideshow with accompanying music facilitates the grieving. With my proposed term, this is a form of online mourning (Zelena, 2014). Most of such content are made with the help of online editing tools - the use of which requires advanced knowledge of software use -, and their textual content and visual composition shows marks characteristic of teenagers and young people. Making a search for synonyms of bereavement and remembrance (such as "RIP”, "in memoriam", "rest in peace”, "remembrance"), I found that, with one exception, the search words bring up a similarly low set of results when narrowing them down to Hungarian-language videos, while the search for the "rest in peace" expression reveals 16,900 results on youtube. com. After a detailed analysis of the video content, it can be asserted that search narrowed down to search words displays only slideshows commemorating deceased people, memorial videos, and content generated to draw the portrait, evoke the memory of the person lost. To sum it up, our previous hypothesis proves to be true, and it can be concluded that social media sites are used by many - consciously or unconsciously - to share announcements of loss as a search result of nearly 26,900 items (25 May 2020) can be considered a high 
rate among Hungarian-language videos. (In 2014, the search started on youtube. com with the same search parameters yielded 12,900 results.) I found that more and more people in the country I am studying publish their loss experiences on their Facebook walls, and meanwhile the distinction between the personal and public discourse and the mass and interpersonal communication becomes unclear (McQuail, 2003).

A detailed analysis of the textual content of memorial videos shows that their makers are probably in the phase of "longing-pursuit" or "displacement (disintegration, regression, chaos) - according to Elizabeth Kübler-Ross's categorization - as lines such as "How could this happen?", "Why you?", "We had so many plans", or "I have no idea what will happen now" are prevailing in comparison with sentences which denote other stages of grief ("I do not understand! The sun shines more faintly...", "At least it does not hurt you any longer, and it is easier for you”, etc.). These are textual elements of the videos randomly chosen and analysed from among the results of the search for the expression "rest in peace" on youtube.com. I will not specify the source due to the possibility to identify the deceased and their memorial videos.

Sentence fragments, incomplete sentences are frequent in the analysed videos, and graphical symbols, such as emoticons, also appear. The memorial videos chosen for detailed analysis by means of "simple random sampling" show similarities concerning their imagery and choice of music. Using this method all the videos appearing in the result list (shortlisted by keyword-based search) had an equal chance of being included in the sample (Zelena, 2014: 22). In this phase of the research, I was trying to answer the question of how the memorial videos accessible on the video sharing sites fit into the stages of grief and whether communal grieving helps the individual loss experience or not. Gábor Gyáni quotes Ricoeur: "It is on the level of collective memory, even more perhaps than on that of individual memory, that the overlapping of the work of mourning and the work of recollection acquires its full meaning" (Ricoeur, 2006: 79). In the collective memory, there are more possibilities to free the libido bound to the lost object and to transfer it elsewhere (Gyáni, 2006). The online memorial short film (as a tool of loss announcement) helps the person who has suffered loss to transform his/ her personal loss into communal loss and thus proceed to the next stage of grief, which, according to the categorization of János Pilling, is "acceptance" (Pilling, 2003), while in the categorization of Alaine Polcz (1998) it is "giving account, review, the adaptation of the relationship”. Ágnes Kárpáty writes the following:

When processing our losses, in addition to the socialization that facilitates the acceptance of death, the possibilities to share loss experiences through ritual, traditions, and collective remembrance are also important. The communal experience of mourning and the meeting of those left behind 
have important integrative psychological functions as death provokes tears and wounds not "only" in the "texture" of personal life but also in that of social life. This "wound" creates a public institution from the flows of personal processing by specifying which actions on which occasion and for how long are needed for the wound to heal. (Kárpáty, 2002)

\section{Disease- and Treatment-Documenting Blogs}

In literature, Eckermann's Conversations with Goethe prepared the ground for the little-known genre of the $21^{\text {st }}$-century loss communication, the so-called disease- and treatment-documenting blogs. In the research process, I had the possibility to meet a recovered young person who had been writing such a blog from the first days of her disease to the end of the three-year check-up. Unfortunately, I also encountered an unfinished text which was unexpectedly interrupted one day (a sorrowful case of death diary based on the terminology used in international literature). According to the information shared in the indepth interview, the patient separated from family and friends faces a complex communication task. I met a blogger whose class- and schoolmates, teammates, teachers and parents' friends inquired after her health in more than 107 text messages and e-mails during her first week spent in the hospital. My informant pointed it out that if she had answered each of these messages in informative and individual responses, she would not have had time for the treatment and could not have concentrated on the healing process. In such cases, the patient starts writing a blog instead of sending personal replies. The main motivation of one of my informants' was the structuring of time. In her detailed blog posts, she described the headaches which were becoming more and more frequent, her growing need for sleep, and then the impact the doctor's announcement about her illness - malignancy frequent among youngsters - made on her. She proceeded step by step with "writing out" her tragedy, recording the visible effect of hair loss, the stages of chemotherapy, and the reactions of her body to the treatment. In the beginning, her readers were her friends and acquaintances, but then the group became wider: relatives of other patients and later even strangers started to regularly follow the illustrated diary of the young blogger. At the beginning of the text, the style of her loss communication exhibits signs of protest and the search for answers. The sad experience of hair loss and inappetence appears together with the longing for her old appearance. When transferred to the sterile room, the blog posts narrate about the drastic end of interpersonal relationships and the painful experience of isolation. At a certain point, however, we realize that we are reading the lines of a young lady who has turned her attention to the future, who accepts the loss of her hair and the radical 
changes her body has undergone. Instead of absence and loss experiences, her text becomes characterized by a hopeful look into the future. The last sentence of the paragraph is a quote from the blogger girl: "At that moment, I decided I should not write about what I have lost but about how I am going to regain it."

\section{Changing Attitudes towards Alternative Methods}

The genre of loss announcement I find the most interesting, and what offers potential for further research is the study of virtual graveyards. After a short registration process, visitors can create a grave and publish photos and a short obituary about the deceased, and later they can light candles and write comments. There are several reasons for the popularity of these websites. One is the geographical distance between the mourner and the grave of the deceased, and the other is the lack of a memorial place in case of an ash scattering ceremony or an urn kept at home. I also found that the possibility and hope for the expansion of personal pain and loss experience into the communal sphere and the wish for social support could also be an explanation. As the act of lighting a candle can be shared on social media sites, an internal dialogue can also be started in the forum of the virtual graveyard or, in certain cases, in the forum "next" to the grave. During my research, I found that people who mourn relatives with the same degree of propinquity start forming a community, in which communal support, lengthy correspondence, the sharing of tragedies and losses frequently occur. I also found that people who mourn their children ensure that a candle is always burning on the grave of their acquaintance's child as well. The following is an acknowledgement to such an act published in the forum: "Thank you for the candles you lit on the grave of my daughter. I am going to return the favour as soon as my PC is working." In addition to virtual memorials, other alternative practices have also emerged, but I will only mention the ones that stirred controversy among the participants of online forums on the topic. The use of biodegradable urns in water ceremonies or scattering the ashes from an airplane are not considered to be as unusual burial methods today as were at the beginning of the century. However, users are shocked if such events are shared on the platforms of social media. Several of my informants were interested in the possibility of using biodegradable urns that can be planted next to the roots or trunks of trees, the so-called burial in natural burial grounds and memorial gardens. When seeing such a post, my informants remained indifferent, or their interest was triggered. The lack of accurate information on alternative burial methods and cremation and the abundance of false information on the Internet stir uncertainty. 


\section{Conclusions}

According to my standpoint, the phenomenon that the personal loss experience announced by users on Web 2.0 expands into communal loss experience following the act of posting is characteristic of the population of Hungary (its total population is 9.6 million). By means of feedback (reactions, comments, replies with different emoticons), the user's loss experience "expands" into communal loss experience. The public compassion, "sharing" the loss helps the personal loss experience in its progress to the next stage. In a study analysing blogs dealing with bereavement and investigating the question of online intimacy and publicity, the authors note: “... a characteristic of our (post-)postmodern age is the manifestation of privacy on the Internet. Personal information and feelings, privacy-related problems are freely shared with the whole world" (Ferdinandy-Szépe, 2010: 59; Szúts, 2019). I presume that such loss communication could relieve anxiety and bring down communication barriers. If the user "has already talked about or shared" his/her pain and loss, the retraumatizing repeated narration might become unnecessary with the occasion of a personal meeting; its place could be taken over by a supportive conversation. To sum it up, I also propose that the personal loss communicated on the platforms of new media facilitates individual processing, thus becoming an organic part of communal processing. My study is focused on a country in which, according to a representative study published in 2015, there are 5 million Facebook users. In conclusion, I would like to refer to the guidelines of the OECD and the Active Ageing programme of the European Commission. I would like to complete the definition of the age-group 50 and over by adding that this is the generation (the baby boomers, those born between 1946 and 1965) whose members are losing their parents belonging to the "veteran generation" (term by Tom Brokaw) in the biggest proportion and are relying on social media when processing this trauma.

\section{References}

Aczél, P.-Andok, M.-Bokor, T. (2015). Múveljük a médiát [We Cultivate the Media]. Budapest: Wolters Kluwer Ltd.

Agger, B. (1996). Trauma and Healing under State Terrorism. London: Zed Books. Ajjan, H.-Hartshorne, R. (2008). Investigating Faculty Decisions to Adopt Web 2.0 Technologies: Theory and Empirical Tests. The Internet and Higher Education 11(2): 71-80.

Anderson, C. (2006). The Long Tail: Why the Future of Business is Selling Less of More. New York: Hyperion. 
Berners-Lee, T.-Hall, W.-Hendler, J.-Shadbolt, N.-Weitzner, D. (2006). Creating a Science of the Web. Science 313(5788): 769-771.

Correa, T.-Hinsley, A. W.-de Zúñiga, H. G. (2010). Who Interacts on the Web?: The Intersection of Users' Personality and Social Media Use. Computers in Human Behavior 26(2): 247-253.

Eckermann, J. P. (1989). Beszélgetések Goethével [Conversations with Goethe]. Transl. by M. Györffy. Budapest: Európa.

Greenfield, S. (2009). ID: The Quest for Identity in the $21^{\text {st }}$ Century. London: Sceptre.

Guo, C.-Saxton G. D. (2013). Tweeting Social Change: How Social Media Are Changing Non-Profit Advocacy. Nonprofit and Voluntary Sector Quarterly 43: 57-79.

Gyáni, G. (2006). Trauma, emlékezet, kultusz [Trauma, Memory, Cult]. Élet és Irodalom 45: 6.

Howley, K. (ed.) (2010). Understanding Community Media. Los Angeles: SAGE Publications Inc.

Jenkins, H.-Ford, S.-Green, J. (2013). Spreadable Media: Creating Value and Meaning in a Networked Culture. New York: New York University Press.

Kárpáty, Á. (2002). A gyász szociológiája (The Sociology of Mourning). Budapest: HAS Centre for Social Sciences, Institute for Political Science, Ethno-Regional Research Centre. Available at: http://mek.oszk.hu/02000/02010/02010.htm (accessed on: 12 March 2017).

McQuail, D. (2010). Mass Communication Theory. $6^{\text {th }}$ ed. Los Angeles: Sage.

Ngwenya, D. (2017). Community Trauma Healing-Theory and Practice. Healing the Wounds of Gukurahundi in Zimbabwe. In: The Anthropocene: PolitikEconomics-Society-Science 19: 63-94.

Pilling, J. (ed.) (2003). A gyász [The Mourning]. Budapest: Medicina.

(2008). Rossz hírek közlése [The Communication of Bad News]. In: Pilling, J. (ed.), Medical Communications. Budapest: Medicina, 306-334.

Polcz, A. (1998). Ideje a meghalásnak [The Time to Die]. Budapest: Pont Publishing.

Ricoeur, P. (2006). Memory, History, Forgetting. Chicago-London: University of Chicago Press.

Scott, J. T.-Maryman, J. (2016). Using Social Media as a Tool to Complement Advocacy Efforts. Global Journal of Community Psychology Practice 7: 1-22. Available at: http://www.gjcpp.org (accessed on: 17 September 2018).

Silver, A.-Kar, B.-Cochran, M. D. (eds.) (2019). Risk Communication and Community Resilience. London: Routledge.

Szépe, O.-Ferdinandy, N. (2010). Intimitás és nyilvánosság. A gyász és a halálhoz kapcsolódó blogok sajátosságai [Intimacy and Publicity. Some of the Peculiarities of Mourning and Death-Related Blogs]. Kharón 1: 47-58. 
Szúts, Z. (2018). Online - Az Internetes kommunikáció és média története, elmélete és jelenségei [Online - The History, Theory, and Phenomena of Online Communication and Media]. Budapest: Wolters Kluwer Kft.

Veszelszki, Á.-Parapatics, A. (2014). A részvételtől a részvétig. A halál megjelenése és gyászmunka a közösségi oldalakon [From Participation to Compassion. The Emergence of Death and Mourning on Social Networks]. Magyar Nyelvór 2: 179-198.

Zelena, A. (2014). A fájlmegosztó oldalak „nyugodj békében” videóinak lélektanáról [On the Psychology of "Rest in Peace" Videos on File-Sharing Sites]. Kharon 4: 18-23.

(2016). Van-e helye gyászjelentésnek közösségi oldalakon? [Are Obituaries Acceptable on Social Media Sites]. Kharon 1: 1-10.

Zing, J. (2020). Sensationalist Media is Exacerbating Racist Coronavirus Fears. We Need to Combat It. People of East Asian Appearance Are Being Abused and Attacked as Coronaracism Becomes a Pandemic. The Guardian [online] 27 February. Available at: https://www.theguardian.com/commentisfree/2020/ feb/28/sensationalist-media-is-exacerbating-racist-coronavirus-fears-we-needto-combat-it (accessed on: 2020.01.21).

\section{Cite as:}

Zeléna, A. (2020). The Psychology of Inclusion on New Media Platforms and the Online Communication. Acta Universitatis Sapientiae, Communicatio 7: 54-67. DOI: 10.2478/auscom-2020-0005. 